\title{
Institutional Quality, Governance and Economic Growth: Evidence from Former Soviet Countries
}

\author{
Ivan Shchegolev ${ }^{1}$, Arshad Hayat*1,2 \\ ${ }^{1}$ International Business, Metropolitan University Prague \\ ${ }^{2} \mathrm{IES}$, Charles University Prague \\ Email: arshad.hayat@mup.cz
}

\begin{abstract}
This paper focuses on the relationships between Institutional Quality, Governance and economic growth. We used World Bank data for five former Soviet Union countries and Worldwide governance index (WGI) data on institutional quality and governance, for the period 1996-2015 and applied Fully Modified Ordinary Least Squares method to investigate the impact of institutional and governance development on economic growth. We found a positive and significant effect of change of Institutional and Governance on economic growth in all the countries. The same is true for the aggregate indicator of institutional quality as well as for individual institutional quality indicators except for Voice and accountability and political stability.
\end{abstract}

Keywords: Institutional quality, governance, economic growth, fully modified ordinary least squares model

JEL Classification: F43, H11

\section{Introduction}

Analysis of institutional impact on economic development has been an important topic in recent years. A wide variety of research is conducted on the impact of institutional quality and governance on economic growth. Majority of the studies found that liberalization in economic and governance processes lead to a stronger economic growth. Dawson (1998) describes why free-market economies grow faster, proves the effect of free-market institutions on productivity and indirect impact on investment, which could also depend on civil liberties. Dawson (1998) states that more liberated and developed organizations could lead to faster economic growth. In another study, North (1990) found that productive elements are more productive when country's institutions are strong. North concluded that with no guarantee for respect of property rights and with corruption there is no place for technological innovations and capital investments which leads to slowing down of economic growth. Dawson also claims that promotion of economic liberty facilitate growth.

In a later empirical research Dawson (2003) concludes that there is a correlation between institutional quality and economic growth and, after conducting the causal analysis, suggests that the level of economic freedom and its components are accompanied by the level of political and individual liberties.

Vijayaraghavan and Ward (2001) analyze different institutional variables across more than 40 countries in the years 1975-1990 and their results show that the security of property rights and size of government are the most important determinants of economic growth.

Fosu, A et.al (2006) provide an overview of the economic development in many African countries. On the one hand, it summarizes that economic growth could be reached by setting up politically accountable governments. Fayissa and Nsiah (2010) made similar research investigating the role of governance in explaining the economic performance of African economies controlling for the conventional sources of growth. Based on the obtained results they confirmed that good governance has a serious and positive effect on economic development. In a similar study, Chang, H (2005) also explains the negative impact of inappropriately established forms and functions of institutions on economic growth.

On the other hand, Acemoglu, D et. al (2008) show examples of exceptions, where some Asian countries with limited economic and institutional freedom have experienced a strong economic growth. 
The paper shows another very important determinant of economic growth, which is a positive economic equilibrium that should be reached by giving more power to those who wants to push through reforms.

Zhuang, J et.al (2010) studying governance and institutions with a connection to the economic growth of developing Asia dispel the notice Asian countries were out of this relationship. They claim growth and level of income of Asian countries is strongly related to governance and institutional quality which is supported by empirical studies. However, they conclude it is not possible to detect a positive relationship between economic growths. It could be explained by measurement problems associated with these indicators to create a reverse causality or by the underestimated role of informal institutions, etc.

In this paper, we analyze the role of institutional quality on economic growth in five former Soviet countries including Azerbaijan, Belarus, Kazakhstan, Russian Federation and Ukraine. The countries included in this research started with similar institutional and governance background as former Soviet nations. However, over the years there has been some institutional divergence among the countries. Therefore, it is of our interest to investigate if the institutional divergence has any impact on the economic growth of these countries.

Each country faced economic regression at the beginning of their independence when GDP contracted and almost every country experienced high inflation. Since then, a lot of economic, political and institutional reforms have been conducted in these countries, but each country followed its own, independent way of development. Elchin Suleymanov and Khatai Aliyev (2015) describe Azerbaijan as the poorest economy in terms of GDP relative to other selected countries. Moreover, political instability, war with Armenia were the main barriers towards establishing a market economy. The third president, Heydar Aliyev, however, signed the peace treaty with Armenia and signed the "Contract of Century" which attracted foreign direct investments (FDI) to the country. The next change was the start of economic reconstruction with the IMF (International Monetary Fund) help. In 1995 adoption of constitution and program of privatization were conducted. All the above led to incredible growth at the beginning of the 2000s till the end of the decade. However, it is important to note, that the biggest source of economic growth was the oil industry progressing from the "Contract of the Century."

Kazakhstan's political situation comparing to the rest of the countries was more stable. Moreover, the transition to a market economy process started with privatization and banking reforms. In order to stabilize the economy, the tough economic policy was followed by the creation of competitive business environment and restrictions of monopolistic activity and price control were also the main objectives. After 2000, Kazakhstan's government supported the middle class and improved education system. However, huge corruption, big dependence on the oil industry, bureaucracy and strong presidential rule remained as the main problems of economic, political and institutional development ${ }^{1,2}$

According to William Cooper (2009), Russia's economy was very close to collapse due to the transfer of economic problems and obligations toward foreign countries of SSSR. Failure to institute tax reform, bankruptcy laws, procedures and property rights and the inability of the government to control government spending worsened the situation. Russia institutional system faced problems such as administrative and bureaucratic obstacles, corruption, and political instability. However, the privatization process, adaptation of constitution, including property rights law were positively influencing the development. On the contrary, Gel'man (2015) lists different institutional reforms, such as real and hypothetical obstacles to monopolist dominance of the ruling group, extensions of the terms of both presidential and parliament and more, which were made to strengthen the power in few hands. These jobs help to understand, that economy becomes more limited and this, based on the theory above, could lead to decreasing the economic growth of Russia. Big economic regression was also observed in Ukraine. However due to stronger political instability, weak legal system and rule of law it suffered a lot more. As a result, it was not possible to create an appropriately working institutional system, environment for competition, investment and growth of new industries. ${ }^{3}$

The economic growth followed in the 2000s was the result of a boom in oligarch owned industries and monetization. Moreover, during this period Ukraine reached a good level of the banking sector. However, Pekka Sutela (2012) points out that the problems such as huge corruption, bureaucracy, oligarchy (also

\footnotetext{
${ }^{1}$ http://e-history.kz/en/contents/view/1542

${ }^{2}$ http://e-history.kz/en/contents/view/784

${ }^{3}$ http://carnegieendowment.org/2012/03/09/underachiever-ukraine-s-economy-since-1991-pub-47451
} 
existing in Russia), weak law system and political instability have not been passed till now.

Grigory Iofee (2004) states that Belarus was not enriched with different minerals comparing to the other four selected countries and economic ties with Russia were disrupted, which made its further economic development more difficult as many major industries were not producing enough and as the results the major part of industrial workers could not work full-time days. The next thing after the beginning of the process of privatization, Belarusian president re-established economic ties with Russia so the industries were able to increase production capacities back. The economic growth was observed till 2014. However, high inflation and huge taxes imposed on enterprises still remained. Moreover, the human rights are not followed properly, political competition does not exist as there is strong Lukashenka's autocratic regime, and the privatization process is still in progress. Therefore, the economic growth has been very slow.

As described above, the institutional and economic development of the countries, it is important to characterize these countries' development by different governance and institutional quality measures in order to analyze the impact of governance and institutional changes on economic growth. Therefore, the next part describes the data used for the analysis, chapter 3 presents the methods and model used in the paper. The results are presented in chapter 4 and chapter 5 concludes the paper.

\section{Data}

This chapter presents the data used including its sources and explanation of variables. Analysis of an impact of institutional governance on economic development has been made using the different indices of both economic development and governance in Azerbaijan, Belarus, Kazakhstan, Russia and Ukraine for the period from 1996 to 2016. All of the selected countries are former Soviet republics, the rest of the Soviet countries have not been included either due to their membership in the European Union, which accelerated their economic development, or because of the lack of data. Data on GDP growth per capita, Government expenditure, Trade, Inflation, Population, for 5 selected countries for period 1996-2016 is obtained from World Bank Open data $\left.{ }^{4}\right]$, Total Investment (\% of GDP) is obtained from IMF Data [5]. The variables describing a country's governance are Voice and accountability, Absence of Violence, Government Effectiveness, Regulatory Quality, Rule of Law, and Control of Corruption. The data on these variables are obtained from Worldwide Governance Indicators provided by the World Bank, compiled by Kaufmann, Kraay, and Zoido-Lobat n (1999) and Kaufmann, Kraay, and Mastruzzi (2005) ${ }^{6}$.

Table 1. Descriptive statistics

\begin{tabular}{lllll}
\hline Variable & Mean & Std. Dev. & Min & Max \\
\hline GDP growth & 5.1225 & 6.5278 & -14.42 & 33.03 \\
Investment & 0.2528 & 0.0756 & 0.13 & 0.58 \\
Inflation & 0.2107 & 0.3653 & -0.09 & 2.94 \\
Population & 0.1022 & 0.8803 & -1.73 & 2.64 \\
Govt Spending & 0.1568 & 0.0429 & 0.08 & 0.27 \\
Trade & 0.9030 & 0.2756 & 0.47 & 1.63 \\
Institutional Quality & 0.2307 & 0.9645 & -1.58 & 1.91 \\
Voice and Accountability & -0.9274 & 0.4693 & -1.77 & 0.09 \\
Political Stability and absence of violence & -0.3616 & 0.6027 & -2.02 & 0.78 \\
Government effectiveness & -0.6621 & 0.2505 & -1.13 & -0.04 \\
Regulatory quality & -0.6518 & 0.4113 & -1.77 & -0.03 \\
Rule of law & -0.9178 & 0.1834 & -1.34 & -0.44 \\
Control of corruption & -0.9432 & 0.2409 & -1.45 & -0.3 \\
\hline
\end{tabular}

Table 1 presents descriptive statistics of data on GDP growth per capita (in \%), Total investment (\%

\footnotetext{
${ }^{4}$ The World Bank database can be accessed from http://databank.worldbank.org/data/home.aspx

${ }^{5}$ The IMF database can be accessed from http://www.imf.org/en/Data

${ }^{6}$ WGI indicators database and methodology can be accessed at http://info.worldbank.org/governance/wgi/\#home
} 
of GDP), Inflation, Population growth (\%), Government spending (\% of GDP), Trade (Exports + Imports $/ G D P$ ), Worldwide Governance Indicators (-2.5 to 2.5 range for estimates), and Institutional estimates, which are the average indices for Governance indicators. The measures are further described in appendix A1. Table 2 presents Initial GDP (billions of $\$$ ) which is included in the work in order to show the differences in production of the selected countries (2 variables from the beginning of each decade were selected: Initial GDP in 1996 and in 2006) and income groups of the selected countries according to The World Bank classification (low, lower-middle, upper-middle, high income groups). The table is shown in appendix A2. ${ }^{7}$

\section{Methods and Model}

Different modern econometric techniques are used in order to investigate the relationship among variables. The study analyses the impact of Institutional Quality and Governance on economic development of Azerbaijan, Belarus, Kazakhstan, Russia and Ukraine based on the panel data using the Fully Modified Ordinary Least Squares (FMOLS). The model was developed and introduced by Fillip and Hansen (1990) in order to analyze long-run macroeconomic relationships.

In order to estimate the impact of institutional quality on economic growth in the former soviet countries, the following panel data model is estimated.

$$
\text { Growth }_{i, t}=\beta_{0}+\beta_{1} \text { INS }_{i, t}+\beta_{2} X_{i, t}+\varepsilon_{i, t}
$$

where Growth $_{\mathrm{i}, \mathrm{t}}$ represents GDP per capita growth rate for country i during time $t$, INS IN.t $_{\text {represent }}$ institutional quality variables, such as Institutional Quality index which is the average value for Worldwide Governance Indicators for country i during time t, X represents all the control variables that affect economic growth in a country. These variables are Total investment (in \% of GDP), Inflation, Population growth (in \%), Government spending (\% of GDP), Trade (Exports + Imports/GDP), (-2.5 to 2.5 range for estimates). In order to estimate the above model (1), The Fully Modified Ordinary Least Squares (FMOLS) model was used.

Bashier and Siam (2014) state that the FMOLS method gives an advantage compared to other models by introducing an appropriate correction in order to overcome the inference problem so the t-test for long-run estimates are valid. Bashier and Siam referring to Rukhsana and Shahbaz (2008) also add that "this method utilizes Kernal estimators of the Nuisance parameters that affect the asymptotic distribution of the OLS estimator. In order to achieve asymptotic efficiency, this technique modifies least squares to account for serial correlation effects and test for the endogeneity in the regressors that result from the existence of Co-integrating Relationships".

According to the Fillip and Hansen study (1990), Bilal Mehmood and Amna Shahid (2014) confirm that the FMOLS provides optimal estimates of cointegrating regressions by modifying least squares to explicate serial correlation effects and for the endogeneity in the regression which arise from the existence of a cointegrating relationship. They describe the model as following equation:

The FM-OLS estimator is given by:

$$
\widehat{\theta}=\left[\begin{array}{c}
\hat{\beta} \\
\hat{\gamma}_{1}
\end{array}\right]=\left(\Sigma_{\mathrm{t}=1}^{\mathrm{T}} \mathrm{Z}_{\mathrm{t}} \mathrm{Z}_{\mathrm{t}}{ }^{\prime}\right)^{-1}\left(\Sigma_{\mathrm{t}=1}^{\mathrm{T}} \mathrm{Z}_{\mathrm{t}} \mathrm{y}_{\mathrm{t}}^{*}-\mathrm{T}\left[\begin{array}{c}
\hat{\lambda}_{12}^{*} \\
0
\end{array}\right]\right)
$$

where $\mathrm{Z}_{t}=\left(X_{t}^{\prime}, D_{t}^{\prime}\right)^{\prime}$. The key to FM-OLS estimation is the construction of long-run covariance matrix estimators $\widehat{\Omega}$ and $\widehat{\Lambda}$. Before describing the options available for computing $\widehat{\Omega}$ and $\widehat{\Lambda}$, it is needed to define the scalar estimator:

$$
\widehat{\omega}_{1.2}=\widehat{\omega}_{11}-\widehat{\omega}_{12} \widehat{\Omega}_{22}^{-1} \widehat{\omega}_{21}
$$

which may be interpreted as the estimated long-run variance of $\hat{v}_{1 t}$ conditional to $\hat{v}_{2 t}$.

\section{Interpretation of FM-OLS Results}

The analysis is made using the above described Fully Modified Ordinary Least Squares (FMOLS) through 5 cross-sections and time series data from 1996 to 2016. Impact of each variable of Institutional Quality and economic development on Economic growth is identified independently. Therefore, the

\footnotetext{
${ }^{7}$ https://blogs.worldbank.org/opendata/new-country-classifications-income-level-2017-2018
} 
model contains incorporates GDP growth as the dependent variable whereas Institutional Quality index (Institutional quality), WGI indices (Voice and accountability, Political stability and absence of violence, Government effectiveness, Control of corruption, Regulatory quality and Rule of Law) and economic development indices (Inflation, Population, Investment, Trade, Government spending) are independent variables.

Table 2. Institutional Quality versus Economic Growth: Does Institutional Quality affect Economic Growth? FMOLS estimation. Dependent Variable: Real GDP per Capita growth (1996-2015)

\begin{tabular}{lcc}
\hline Variable & Coefficient & P-Value \\
\hline Institutions & $0.321846^{*}$ & 0.0925 \\
Inflation & 2.860642 & 0.3352 \\
Population & $-9.571065^{* * *}$ & 0.0000 \\
Investment & $29.96380^{* * *}$ & 0.0000 \\
Trade & $18.19777^{* * *}$ & 0.0000 \\
Govt Spending & $-84.97782^{* * *}$ & 0.0000 \\
\hline
\end{tabular}

Independent variables are Total investment (\% of GDP), Inflation, Population growth (\%), Government spending (\% of GDP), Trade (Exports + Imports/GDP), and Institutions which is the average index for Worldwide Governance Indicators.

*** indicates a significance at a $1 \%$ confidence interval, ${ }^{* *}$ indicates a significance at a $5 \%$ confidence interval and * indicates a significance at a 10\% confidence interval. + H0: No Serial Autocorrelation

Firstly, the analysis was made for the Institutions, as the average index for all the Worldwide Governance indicators. The results are shown in the table 2. It is obvious from the table that Worldwide Governance Indicators in average have a small positive and significant at $10 \%$ effect on the economic growth. The Inflation effect is positive and insignificant, Investment and Trade positively and significantly at $1 \%$ affects economic growth, Population growth, Government spending have a negative and significant at $1 \%$ impact on the economic growth.

Secondly, the results of the separate analyses for the Worldwide Governance Indicators are shown in table 3. The FM-OLS analysis conducted for the GDP per Capita growth as dependable variable and Voice and Accountability and economic development indices as independent variables suggests that Voice and Accountability has a positive but insignificant effect on GDP growth, while Inflation, Population growth, and Government spending have a negative and significant at a $1 \%$ confidence interval effect. Investment and Trade have positive and significant at a $1 \%$ confidence interval effect. The test conducted for the Rule of Law suggests the positive and significant at $1 \%$ effect of the Rule of Law, Investment and Trade on the GDP per Capita growth. Inflation, Population growth, and Government spending have a positive and significant at $1 \%$ effect on economic growth. From the analysis of impact of the Control of Corruption follows that the Control of Corruption, Investment and Trade have a positive and significant at $1 \%$ effect on economic growth. Inflation, Population growth and Government spending have a positive and significant at $1 \%$ effect on economic growth.

Analysis made for the impact of Regulatory Quality shows the positive and significant at $1 \%$ impact of Regulatory Quality, Investment and Trade on the GDP growth per capita. The rest, Inflation, Population growth, Government spending, have a negative and significant at $1 \%$ impact on the economic growth.

Political Stability as the one of the six World Governance Indicators has a negative but insignificant effect on the economic growth. Investment and Trade have the positive and significant at $1 \%$ impact on the economic growth of the selected countries. Inflation, Population growth, Government spending, have a negative and significant at $1 \%$ impact on the economic growth.

In the next analysis, economic growth is positively and significantly affected by the Governance Effectiveness, Investments and Trade and negatively and significantly by Inflation, Population growth, Government spending.

All the results above can be explained as the high regulatory quality, control of corruption or (low level of corruption), rule of law and effective government are the major forces leading economy to growth. 
Table 3. Institutional Quality versus Economic Growth: Does Institutional Quality affect Economic Growth? FMOLS estimation. Dependent Variable: Real GDP per Capita growth (1996-2015)

\begin{tabular}{ccccccc}
\hline \multirow{2}{*}{ Variable } & \multicolumn{6}{c}{ Institutional Quality Indicators } \\
\cline { 2 - 7 } & VA & RL & CC & RQ & PS & GE \\
\hline \multirow{2}{*}{ Institutional Quality } & 2.962761 & $11.78904^{* * *}$ & $10.5639^{* * *}$ & $27.67387^{* * *}$ & -2.081610 & $12.51943^{* * *}$ \\
& $\{2.849018\}$ & $\{3.152548\}$ & $\{1.9075\}$ & $\{8.536924\}$ & $\{1.383101\}$ & $\{1.276747\}$ \\
\hline \multirow{2}{*}{ Inflation } & $-29.67619^{* * *}$ & $-42.49915^{* * *}$ & $-43.2890^{* * *}$ & $-49.05447^{* * *}$ & $-23.79856^{* * *}$ & $-44.24401^{* * *}$ \\
& $\{8.058912\}$ & $\{4.379900\}$ & $\{4.0149\}$ & $\{10.29885\}$ & $\{6.290335\}$ & $\{4.113932\}$ \\
\hline \multirow{2}{*}{ Population } & $-8.437708^{* * *}$ & $-8.500435^{* * *}$ & $-6.3566^{* * *}$ & $-9.235133^{* * *}$ & $-8.230852^{* * *}$ & $-9.663242^{* * *}$ \\
& $\{0.988169\}$ & $\{0.827144\}$ & $\{0.8726\}$ & $\{1.123761\}$ & $\{0.932760\}$ & $\{0.824948\}$ \\
\hline \multirow{2}{*}{ Investment } & $16.55878^{* * *}$ & $10.81907^{* * *}$ & $12.7943^{* * *}$ & 8.083329 & $25.54891^{* * *}$ & $16.34996^{* * *}$ \\
& $\{5.834918\}$ & $\{4.510258\}$ & $\{5.0223\}$ & $\{6.894492\}$ & $\{5.496106\}$ & $\{4.354050\}$ \\
\hline \multirow{2}{*}{ Trade } & $36.35709^{* * *}$ & $46.84353^{* * *}$ & $44.0533^{* * *}$ & $55.01553^{* * *}$ & $31.99747^{* * *}$ & $50.00375^{* * *}$ \\
& $\{4.241486\}$ & $\{3.239719\}$ & $\{3.6030\}$ & $\{8.571129\}$ & $\{3.932160\}$ & $\{3.046293\}$ \\
\hline \multirow{2}{*}{ Govt Spending } & $-109.3850^{* * *}$ & $-119.9912^{* * *}$ & $-123.5270^{* * *}$ & $-134.9297^{* * *}$ & $-130.4555^{* * *}$ & $-168.6831^{* * *}$ \\
& $\{43.31843\}$ & $\{13.63679\}$ & $\{13.8541\}$ & $\{21.44069\}$ & $\{16.38168\}$ & $\{11.99002\}$ \\
\hline
\end{tabular}

Independent variables are Total investment (\% of GDP), Inflation, Population growth (\%), Government spending (\% of GDP), Trade (Exports + Imports/GDP), Worldwide Governance Indicators (-2.5 to 2.5 range for estimates).

*** indicates a significance at a $1 \%$ confidence interval, **indicates a significance at a $5 \%$ confidence interval and

* indicates a significance at a $10 \%$ confidence interval. Values in parenthesis indicate standard errors

\section{Conclusion}

This paper investigated the relationships between economic growth and Institutional Quality and Governance of the selected former USSR countries including Azerbaijan, Belarus, Kazakhstan, Russia and Ukraine in the period from 1996 to 2015. This paper focuses on the impact of changes in Institutional Quality and Governance on the GDP growth. We used institutional quality and governance indicators developed by the Worldwide Governance indicators (WGI) and used panel data Fully Modified Ordinary Least Squares (FMOLS) model to investigate the impact of institutional quality and governance on economic growth in the countries in question.

The study found that the institutional quality variable has a positive significant growth inducing affect in the countries under consideration. The study also found that the individual institutional quality indicators have significant growth enhancing impact in these countries. We found that the GDP growth of the selected countries was positively impacted by the institutional quality indicators including Control of Corruption, Government Effectiveness, Rule of Law and Regulatory Quality. The impact of these variables on economic growth was found to be statistically significant. Besides, we also found that voice and accountability and political stability impacted economic growth positively and negatively respectively. The impact of these variables however, was found to be statistically insignificant. The conclusion of this paper would be applicable to all the former soviet countries that went through a similar economic and institutional transition as the countries included in this paper. However, the results are not necessarily applicable to countries other than the former soviet countries. This is due to the fact that the economies and institutions of these countries went through transition that is very specific to these countries.

Keeping in view the conclusions of this paper, we recommend that the countries included in this study need to improve their governance and institutional quality in order to achieve faster economic growth. More specifically, we recommend raising the standards on rule of law, government effectiveness, control of corruption and regulatory quality to experience speedy economic growth.

Acknowledgement. The authors are grateful for the MUP Grant No. IGS E13-53. 


\section{References}

1. Acemoglu, D and Robinson, J (2008) The Role of Institutions in Growth and Development Review of Economics and Institutions, Vol. 1 - No. 2, http://dx.doi.org/10.5202/rei.v1i2.14

2. Bashier, A and Siam, A (2014) Immigration and Economic Growth in Jordan: FMOLS Approach, ISSN 23490381 (Online)

3. Chang, H (2005) Understanding the Relationship between Institutions and Economic Development- Some Key Theoretical Issues

4. Dawson, J (1998) Institutions, Investment, and Growth: New Cross-Ccountry and Panel Data Evidence, DOI: 10.1111/j.1465-7295.1998.tb01739.x

5. Dawson, J (2003) Causality in the freedom-growth relationship, vol. 19, issue 3

6. Fosu, A and Bates, R and Hoeffler, A (2006) Institutions, Governance and Economic Development in Africa: An Overview, https://doi.org/10.1093/jae/ejk004

7. Gel'man, V (2015) Authoritarian Russia: Analyzing Post-Soviet Regime Changes, DOI: 10.2307/j.ctt155jmv1

8. Mehmood, B and Shahid, A (2014) Aviation Demand and Economic Growth in the Czech Republic: Cointegration Estimation and Causality Analysis

9. Rousso, A (2000) Russia's Transformation: The Prospects for Democracy, Vol 7, issue 1

10. Vijayaraghavan, M and Ward, W (2001) Institutions and Economic Growth: Empirical Evidence for a CrossNational Analysis

11. Vasiliev, S (2000) Overview of Structural Reforms in Russia after 1998 Financial Crisis

12. Zhuang, J and Emannuel, D and Langman-Martin, A (2010) Governance and Institutional Quality and the Links with Economic Growth and Income Inequality: With Special Reference to Developing Asia, DOI: $10.2139 / \operatorname{ssrn} .1619116$ 


\section{Appendix}

\section{A1}

\begin{tabular}{|c|c|c|}
\hline Variable & Description & Source \\
\hline GDP & Growth Rate of Real GDP per capita & The World bank \\
\hline Investment & Gross domestic capital formation (Gross domestic investment) & The World bank \\
\hline Inflation & Rate of growth of consumer price index & The World bank \\
\hline Population & Growth rate of population of the country & The World bank \\
\hline Government expenditure & Ration of government expenditure to GDP & The World bank \\
\hline Trade & Ration of import and export to the GDP & The World bank \\
\hline Voice and Accountability & $\begin{array}{l}\text { Voice and Accountability is the perception of extent to which country's } \\
\text { citizens are able to participate in selecting their government, freedom of } \\
\text { expression, freedom of association, and a free media. }\end{array}$ & WGI \\
\hline Political Stability & $\begin{array}{l}\text { Political Stability and Absence of Violence measures probability of } \\
\text { political instability, politically motivated violence, terrorism. }\end{array}$ & WGI \\
\hline Government Effectiveness & $\begin{array}{l}\text { Government Effectiveness captures the quality of public services, the } \\
\text { quality of civil service and the degree of its independence from political } \\
\text { pressures, the quality of policy formulation and implementation, and the } \\
\text { credibility of the government's commitment to such policies. }\end{array}$ & WGI \\
\hline Regulatory Quality & $\begin{array}{l}\text { Regulatory quality is the ability of the government to formulate and } \\
\text { implement sound policies and regulations that permit and promote } \\
\text { private sector development. }\end{array}$ & WGI \\
\hline Rule of Law & $\begin{array}{l}\text { Rule of Law extent to which agents have confidence in and abide by the } \\
\text { rules of society, and in particular, the quality of contract enforcement, } \\
\text { property rights, the police, and the courts, as well as the likelihood of } \\
\text { crime and violence. }\end{array}$ & WGI \\
\hline Control of Corruption & $\begin{array}{l}\text { Control of Corruption is the degree to which public power is exercised for } \\
\text { private gain, including both petty and grand forms of corruption, as well } \\
\text { as "capture" of the state by elites and private interests. }\end{array}$ & WGI \\
\hline
\end{tabular}

A2

\begin{tabular}{llcc}
\hline Country & Income Group & Initial GDP 1996 & Initial GDP 2006 \\
\hline Azerbaijan & high income & 3.18 & 20.98 \\
Belarus & upper middle & 14.76 & 36.96 \\
Kazakhstan & upper middle & 21.04 & 81.00 \\
Russia & high income & 391.72 & 989.93 \\
Ukraine & lower middle & 44.56 & 107.75 \\
\hline
\end{tabular}

